\title{
Functional and molecular characterization of single serial killer CAR+ T cells demonstrates adaptive modification of behavior and fate based on tumor cell density
}

\author{
Navin Varadarajan ${ }^{1 *}$, Ivan Liadi ${ }^{1}$, Gabrielle Romain ${ }^{1}$, Harjeet Singh², Laurence Cooper ${ }^{2}$ \\ From Society for Immunotherapy of Cancer 29th Annual Meeting \\ National Harbor, MD, USA. 6-9 November 2014
}

T cells genetically modified to express a CD19-specific chimeric antigen receptor (CAR) for the investigational treatment of $\mathrm{B}$ cell malignancies comprise a heterogeneous population, and their ability to persist and participate in serial killing of tumor cells is a predictor of therapeutic success. We developed Timelapse Imaging Microscopy In Nanowell Grids (TIMING) to dynamically analyze thousands of interactions between $\mathrm{T}$ cells and tumor cells. Our results demonstrate that while $\mathrm{CAR}^{+} \mathrm{T}$ cells launch fullycompetent anti-tumor responses as defined by polarized motility, serial-killing and IFN- $\gamma$ secretion, the cytolytic functionality of $\mathrm{CAR}^{+} \mathrm{T}$ cells must be quantified in the context of their ability to resist apoptosis. The ability of killer $\mathrm{CAR}^{+} \mathrm{T}$ cells to adaptively modify both cell-intrinsic (polarization and motility) and extrinsic (conjugation and kinetics of tumor-cell death) behavior was modulated by number of tumor cell encounters. By comparing both the serial killer and single killer $\mathrm{CAR}^{+} \mathrm{T}$ cells it appears that the propensity and kinetics of effector apoptosis was markedly different, effectors underwent apoptosis at higher frequencies $(50 \%$, single target killers, vs $28 \%$, serial killers) and faster kinetics (time to apoptosis: $256 \pm 12$ minutes, single target; vs. $396 \pm 25$ minutes, multiple targets; $\mathrm{p}$-value $<0.0001$ ) (Figure 1). These data indicate that activation for lysis through multiple targets as opposed to prolonged contact with a single target reduces the propensity for effector apoptosis. Although the mechanistic basis for the responsiveness of these $\mathrm{T}$ cells to
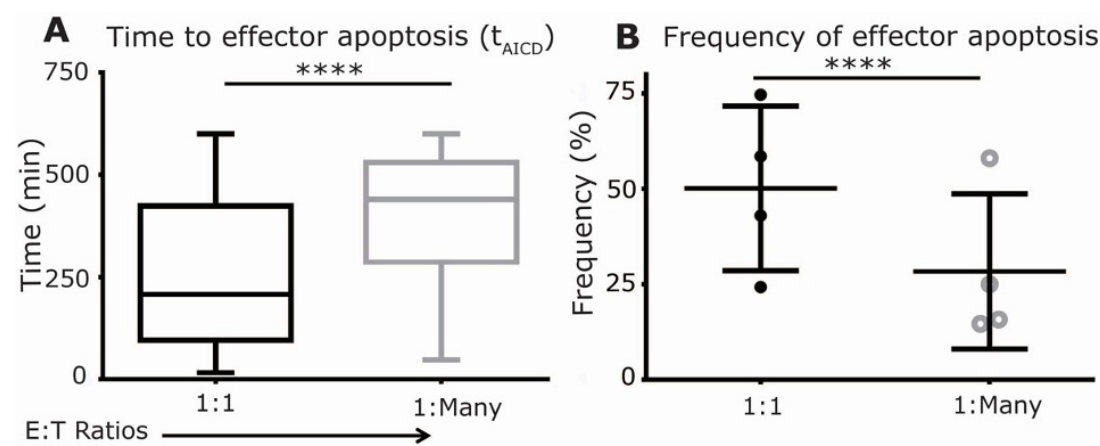

Figure 1 Frequency and kinetics of effector apoptosis are dependent on functional activation by varying numbers of tumor cells. (A) Box and whisker plots (extremities indicate range) of the distribution of single $C A R^{+} T$ cells undergoing AICD. (B) Donor variation in the average frequencies of apoptotic killer CAR ${ }^{+} \mathrm{T}$ cells. P-values were computed using an unpaired two-tailed t-test.

'University of Houston, TX, USA

Full list of author information is available at the end of the article 
antigen/target density is not known, it is conceivable that the continuous propagation of these cells on irradiated aAPC at defined ratios, allows for balanced activation while minimizing AICD. These data could provide mechanistic insights into observations that infused $\mathrm{CAR}^{+}$ $\mathrm{T}$ cells swell in number and produce high levels of cytokine in response to addressing large numbers of $\mathrm{CD} 19^{+}$tumor cells, but then decline in number as the tumor bioburden is lowered due to the serial killing by effector $\mathrm{T}$ cells. Our findings emphasize the notion that motility and persistence (resistance to apoptosis), in addition to direct cytolytic activity, may serve as criteria to rapidly evaluate $\mathrm{CAR}^{+} \mathrm{T}$ cell potency. We anticipate that our findings and the TIMING methodology may provide a rapid approach for assessing the impact of CAR designs and sub-populations of cells modified to redirect specificity.

\section{Authors' details}

${ }^{1}$ University of Houston, TX, USA. ${ }^{2}$ University of Texas M.D. Anderson Cancer Center, Houston, TX, USA.

Published: 6 November 2014

doi:10.1186/2051-1426-2-S3-P145

Cite this article as: Varadarajan et al:: Functional and molecular characterization of single serial killer CAR+ T cells demonstrates adaptive modification of behavior and fate based on tumor cell density. Journal for ImmunoTherapy of Cancer 2014 2(Suppl 3):P145.
Submit your next manuscript to BioMed Central and take full advantage of:

- Convenient online submission

- Thorough peer review

- No space constraints or color figure charges

- Immediate publication on acceptance

- Inclusion in PubMed, CAS, Scopus and Google Scholar

- Research which is freely available for redistribution

Submit your manuscript at www.biomedcentral.com/submit 